\title{
Pengembangan lembar kegiatan siswa (LKS) berbasis teori pertumbuhan pemahaman matematis pirie kieren pada materi fungsi linier kelas X SMA/MA
}

\author{
Reni Albertin Putri, Susiswo* \\ Universitas Negeri Malang, Jl. Semarang No. 5 Malang, Jawa Timur, Indonesia \\ *Penulis korespondensi, Surel: susiswo.fmipa@um.ac.id
}

Paper received: 01-09-2021; revised: 15-09-2021; accepted: 30-08-2021

\begin{abstract}
Abstrak
Tujuan penelitian pengembangan ini adalah untuk menghasilkan LKS berbasis teori pertumbuhan pemahaman matematis Pirie Kieren yang bersifat valid, praktis dan efektif untuk memahamkan siswa terhadap materi fungsi linier kelas X SMA/MA. Pengembangan LKS ini menggunakan model Plomp yang meliputi tiga tahap yaitu fase pendahuluan, fase pengembangan, dan fase assesmen. Uji coba LKS dilakukan terhadap siswa SMA Nasional Malang dengan dua kali uji coba yakni uji coba kelompok kecil dan uji coba kelompok besar. Dari hasil uji validasi LKS dinyatakan valid dengan rata-rata skor kevalidan mencapai 3,925. LKS dinyatakan praktis berdasarkan respon baik guru dan siswa ditunjukkan oleh angket yang diberikan. Rata-rata skor angket respon siswa uji kelompok kecil mencapai 3,25, rata-rata skor angket respon siswa uji kelompok besar mencapai 3,48 , sedangkan rata-rata skor angket respon guru mencapai 4. LKS dinyatakan efektif berdasarkan hasil tes siswa. Pada uji kelompok kecil 100 persen siswa lolos KKM sedangkan pada uji kelompok besar 91 persen siswa lolos KKM.
\end{abstract}

Kata kunci: lembar kegiatan siswa; teori pertumbuhan pemahaman matematis Pirie Kieren; fungsi linier

\section{Pendahuluan}

Salah satu tujuan pembelajaran matematika di Indonesia adalah mendorong siswa untuk mengembangkan kemampuan pemahaman matematis mereka. Hal tersebut tertera dalam Permendikbud no 58 tahun 2014 tentang Kurikulum SMP/MTs yang menyatakan bahwa pembelajaran matematika memiliki tujuan agar peserta didik dapat memahami konsep matematika, yang meliputi menjelaskan keterkaitan antarkonsep dan menggunakan konsep maupun algoritma, secara luwes, akurat, efisien, dan tepat, dalam pemecahan masalah. Skemp (dalam Schwartz dkk, 2001) menyatakan bahwa pemahaman matematis merupakan kemampuan mengasimilasi atau menggabungkan skema yang tepat.

Bertolak belakang dengan tujuan tersebut, kondisi saat ini menunjukkan lemahnya kemampuan pemahaman matematis siswa di Indonesia. Sutisna dkk (2016) dalam penelitiannya terkait perbedaan kemampuan pemahaman matematis pada kelas tematik dan kelas tematik menggunakan RME, menemukan fakta bahwa rata-rata pemahaman matematis siswa hanya mencapai kisaran 55 hingga 62 saja. Fakta lain juga ditemukan oleh Cahyati dkk (2017) yang mengkaji terkait lapisan pemahaman matematis siswa SMP dalam mengerjakan soal TIMSS (Trends in International Mathematics and Science Study) pada topik sifat-sifat geometris dari sudut dan bentuk geometris. Pada penelitian ini diperoleh fakta bahwa siswa hanya menempati lapisan formalizing bahkan ada yang hanya mencapai pada image having.

Fakta-fakta dari beberapa literatur tersebut selaras dengan temuan yang diperoleh penulis ketika melakukan Kajian Praktek Lapangan di SMA Nasional Malang. Berdasarkan observasi pendahuluan ditemukan banyak siswa memiliki kemampuan pemahaman 
matematis yang rendah pada materi fungsi linier. Hal tersebut dibuktikan lemahnya kemampuan mereka dalam menyatakan ulang suatu konsep, memberikan contoh dan bukan contoh, mengubah suatu konsep dari satu representasi ke representasi lain, serta menggunakan berbagai prosedur untuk memecahkan masalah terkait fungsi linier. Setelah melakukan penyelidikan lebih lanjut diperoleh, penulis menemukan alasan kondisi tersebut terjadi. Yaitu pembelajaran guru yang masih bersifat teacher oriented serta kurangnya ketersedian bahan ajar yang membantu mereka memahami fungsi linier secara mandiri dan sistematis. Oleh karena itu, untuk menanganinya peneliti merumuskan sebuah solusi yakni dilakukannya pengembangan bahan ajar berupa LKS berbasis teori pertumbuhan pemahaman matematis Pirie Kieren.

LKS (Lembar Kegiatan Siswa) atau student worksheet menurut Depdiknas (2008) merupakan lembaran-lembaran yang memuat tugas yang perlu dikerjakan oleh peserta didik. Teori pertumbuhan pemahaman matematis Pirie Kieren adalah teori yang membahas lapisan pemahaman matematis yang bersifat urut, dinamis, dan bertingkat yang terdiri dari delapan lapisan pemahaman matematis meliputi primitive knowing, image making, image having, property noticing, formalising, observing, structuring, dan inventising (Pirie dan Kieren, 1994). Oleh karena itu, yang dimaksud dengan LKS berbasis teori pertumbuhan pemahaman matematis Pirie Kieren adalah LKS yang serangkaian langkah dan bentuk penugasan di dalamnya disusun secara sistematis sesuai dengan lapisan pertumbuhan pemahaman matematis Pirie Kieren dengan rincian penugasan sebagai berikut : (1) Lapisan penugasan primitive knowing untuk menggali kemampuan awal siswa (apersepsi), (2) lapisan penugasan image making untuk mendorong siswa menggunakan pengetahuan sebelumnya dalam memahami pengetahuan baru, (3) lapisan penugasan image having untuk mendorong siswa memahami suatu topik tanpa harus melakukan aktivitas tertentu, (4) lapisan penugasan property noticing untuk mendorong siswa menemukan sifat khusus suatu konsep, (5) lapisan penugasan formalising untuk mendorong siswa mengutarakan konsep secara formal, (6) lapisan penugasan observing untuk mendorong siswa menerapkan konsep formal yang telah diperoleh, (7) lapisan penugasan structuring untuk mendorong siswa menarik kesimpulan sifat-sifat konsep serta penggunaannya, (8) lapisan penugasan inventising untuk mendorong siswa mengutarakan pertanyaan baru yang dapat memunculkan konsep.

Tujuan pengembangan LKS ini adalah untuk menghasilkan LKS berbasis teori pertumbuhan pemahaman matematis yang valid, praktis dan efektif untuk memahamkan siswa terhadap materi fungsi linier kelas X SMA/MA. Kriteria kevalidan terukur berdasarkan skor validasi dari validator. Kriteria kepraktisan terukur berdasarkan skor angket respon guru dan siswa. Sedangkan kriteria keefektifan LKS terukur berdasarkan skor hasil tes siswa.

\section{Metode}

Model pengembangan yang digunakan dalam pengembangan LKS ini adalah model pengembangan Plomp. Plomp \& Nieveen (2010) menyatakan bahwa terdapat tiga tahap yang harus dilakukan dalam penelitian pengembangan. Adapun tahapan tersebut adalah fase preliminary research (fase pendahuluan), prototyping phase (fase prototipe/pengembangan), dan assesment phase (fase assesmen). Fase Pendahuluan merupakan fase awal penelitiaan yang dilakukan untuk memperoleh informasi terkait analisis konteks, studi literatur, dan pengembangan kerangka konseptual untuk kegiatan penelitian. Fase Pengembangan merupakan tahap inti dari proses pengembangan. Terdiri dari proses perancangan produk LKS dan instrumen terkait serta evaluasi formatif untuk menilai kevalidan produk. Sedangkan fase assesmen merupakan fase untuk 
mengevaluasi dan menyimpulkan apakah produk yang dihasilkan telah sesuai dengan spesifikasi produk yang telah ditetapkan sebelumnya melalui uji lapangan.

Validasi LKS dilakukan untuk mengukur kevalidan LKS berdasarkan kriteria-kriteria validitas yang telah ditetapkan. Validasi dilakukan olah satu orang dosen matematika sebagai validator ahli dan satu orang guru matematika SMA sebagai validator praktisi. Data hasil validasi yang telah didapatkan akan direkapitulasi dan dianalisis menggunakan teknik analisis rata-rata menurut Hobri (2010:90) dengan sedikit modifikasi. Nilai rata-rata ditentukan berdasarkan nilai rata-rata setiap aspek penilaian pada lembar validasi berdasarkan rumus:

$$
A_{i}=\frac{\sum_{j=1}^{n} x_{j}}{n \cdot m}
$$

Keterangan: $\quad A_{i}=$ Rerata nilai untuk aspek ke-i

$x_{j}=$ Jumlah skor penilaian validator ke-j untuk aspek ke-i

$m=$ banyaknya indikator dalam aspek ke-i

$n=$ banyakanya validator

Selanjutnya rerata total untuk semua aspek dihitung menggunakan rumus sebagai berikut.

$$
V_{a}=\frac{\sum_{i}^{n} A_{i}}{n}
$$

Keterangan: $\quad V_{a}=$ Rerata total untuk semua aspek

$A_{i}=$ Rerata untuk aspek ke-i

$n=$ banyaknya aspek

Hasil analisa data disesuaikan dengan kriteria persentase hasil validasi yang diadopsi dari Hobri (2010:91) dengan modifikasi sebagai berikut.

Tabel 1 Kriteria Penilaian Hasil Validasi

\begin{tabular}{cll} 
Presentase & Kriteria Kevalidan & Keterangan \\
\hline$V_{a}=4$ & Sangat Valid & Tidak Perlu Revisi \\
\hline $3,25 \leq V_{a}<4$ & Valid & Tidak Perlu Revisi \\
\hline $2,5 \leq V_{a}<3,25$ & Cukup Valid & Perlu Revisi \\
\hline $1,75 \leq V_{a}<2,5$ & Kurang Valid & Perlu Revisi \\
\hline $1 \leq V_{a}<1,75$ & Tidak Valid & Revisi Total
\end{tabular}

Kriteria penentuan kepraktisan diukur melalui penghitungan rata-rata skor angket respon guru dan siswa. Teknik penghitungan yang dilakukan sama dengan teknik penghitungan skor rata-rata validasi LKS di atas dengan skor penilaian tertinggi untuk masing-masing butir penilaian pada lembar validasi maupun angket adalah 4. Sedangkan kriteria keefektifan diukur berdasarkan presentase banyak siswa yang lolos KKM $(\geq 70)$ dengan rumus sebagai berikut.

$$
p=\frac{x}{n} \cdot 100 \%
$$

Keterangan: $\quad p=$ Presentase subjek uji coba yang lolos KKM

$x=$ Banyak subjek uji coba yang lolos KKM

$n=$ Banyak subjek uji coba 


\section{Hasil dan Pembahasan}

Berdasarkan tahap validasi LKS oleh dua validator, diperoleh hasil seperti disajikan dalam Tabel 2 berikut.

Tabel 2 Data Hasil Validasi Lembar Kegiatan Siswa

\begin{tabular}{llllll}
\hline No & Aspek yang Dinilai & $\boldsymbol{x}_{\mathbf{1}}$ & $\boldsymbol{x}_{\mathbf{2}}$ & $\boldsymbol{A}_{\boldsymbol{i}}$ & Kriteria Kevalidan \\
\hline 1. & Kelayakan Isi & 15 & 16 & 3.875 & Valid \\
\hline 2. & Kelayakan Bahasa & 12 & 12 & 4 & Sangat Valid \\
\hline 3. & Kelayakan Penyajian & 12 & 12 & 4 & Sangat Valid \\
\hline 4. & Kelayakan Grafik & 7 & 8 & 3,75 & Valid \\
\hline 5. & $\begin{array}{l}\text { Kesesuain dengan } \\
\text { Teori Pirie Kieren }\end{array}$ & 36 & 36 & 4 & Sangat Valid \\
\hline & Paparan data pada Tabel 2 menunjukkan & & \\
\hline
\end{tabular}
telah memenuhi kriteria kevalidan yang tinggi. Ketika data tersebut diolah menggunakan rumus $V_{a}=\frac{\sum_{i=1}^{n} A_{i}}{n}$, menunjukkan bahwa hasil $\boldsymbol{V}_{\boldsymbol{a}}$ (rerata skor kevalidan untuk semua aspek) LKS adalah 3,925. Oleh karena itu, dapat disimpulkan LKS bersifat valid.

Setelah dilakukan dua kali uji coba yaitu uji coba kelompok kecil dan uji coba kelompok besar, diperolehlah data angket respon siswa dan guru serta hasil tes siswa. Adapun data skor angket respon guru dan siswa tertera dalam Tabel 3, 4, dan 5 berikut.

Tabel 3 Data Hasil Uji Kepraktisan Kelompok Kecil

\begin{tabular}{l|l|l}
\hline Butir penilaian ke- & Rata-rata skor respon siswa (Vi) & Kriteria Kepraktisan \\
\hline 1 & 3 & Cukup Praktis \\
\hline 2 & 2,75 & Cukup Praktis \\
\hline 3 & 3,5 & Praktis \\
\hline 4 & 3,25 & Praktis \\
\hline 5 & 3 & Cukup Praktis \\
\hline 6 & 3 & Cukup Praktis \\
\hline 7 & 4 & Sangat Praktis \\
\hline 8 & 3,5 & Praktis
\end{tabular}

Paparan data pada Tabel 3 menunjukkan bahwa terdapat beragam respon yang diberikan siswa terhadap butir-butir kriteria yang diajukan. Meskipun demikian ternyara ketika data tersebut diolah menggunakan rumus $P_{a}=\frac{\sum_{i=1}^{n} V_{i}}{n}$, menunjukkan bahwa hasil $\boldsymbol{P}_{\boldsymbol{a}}$ (rerata skor kepraktisan untuk semua butir) respon siswa adalah 3,25. Oleh karena itu, dapat disimpulkan LKS bersifat praktis.

Tabel 4 Data Hasil Uji Kepraktisan Kelompok Besar

\begin{tabular}{l|l|l|l|l|l|l|l|l}
\hline $\begin{array}{l}\text { Butir } \\
\text { penilaian ke- }\end{array}$ & $\mathbf{1}$ & $\mathbf{2}$ & $\mathbf{3}$ & $\mathbf{4}$ & $\mathbf{5}$ & $\mathbf{6}$ & $\mathbf{7}$ & $\mathbf{8}$ \\
\hline $\begin{array}{l}\text { Rata-rata } \\
\text { skor respon } \\
\text { siswa (Vi) }\end{array}$ & 3,26 & 3,26 & 3,48 & 3,48 & 3,48 & 3,57 & 3,61 & 3,70 \\
\hline $\begin{array}{l}\text { Kriteria } \\
\text { Kepraktisan }\end{array}$ & Praktis & Praktis & Praktis & Praktis & Praktis & Praktis & Praktis & Praktis
\end{tabular}

Paparan data pada Tabel 4 menunjukkan bahwa setiap butir kriteria pada angket, mendapat skor respon yang tinggi sehingga memenuhi tingkat kepraktisan yang tinggi. 
Ketika data tersebut diolah menggunakan rumus $P_{a}=\frac{\sum_{i}^{n} V_{i}}{n}$, menunjukkan bahwa hasil $\boldsymbol{P}_{\boldsymbol{a}}$ (rerata skor kepraktisan untuk semua butir) respon siswa adalah 3,48. Oleh karena itu, dapat disimpulkan LKS bersifat praktis.

Tabel 5 Data Hasil Uji Kepraktisan (Angket Respon Guru) Kelompok Besar

\begin{tabular}{l|c|c|c|c|c|c|c|c}
\hline Butir penilaian ke- & $\mathbf{1}$ & $\mathbf{2}$ & $\mathbf{3}$ & $\mathbf{4}$ & $\mathbf{5}$ & $\mathbf{6}$ & $\mathbf{7}$ & $\mathbf{8}$ \\
\hline $\begin{array}{l}\text { Rata-rata skor } \\
\text { respon siswa (Vi) }\end{array}$ & 4 & 4 & 4 & 4 & 4 & 4 & 4 & 4 \\
\hline $\begin{array}{l}\text { Kriteria } \\
\text { Kepraktisan }\end{array}$ & $\begin{array}{l}\text { Sangat } \\
\text { Praktis }\end{array}$ & $\begin{array}{l}\text { Sangat } \\
\text { Praktis }\end{array}$ & $\begin{array}{l}\text { Sangat } \\
\text { Praktis }\end{array}$ & $\begin{array}{l}\text { Sangat } \\
\text { Praktis }\end{array}$ & $\begin{array}{l}\text { Sangat } \\
\text { Praktis }\end{array}$ & $\begin{array}{l}\text { Sangat } \\
\text { Praktis }\end{array}$ & $\begin{array}{l}\text { Sangat } \\
\text { Praktis }\end{array}$ & $\begin{array}{l}\text { Sangat } \\
\text { Praktis }\end{array}$
\end{tabular}

Paparan data pada Tabel 5 menunjukkan bahwa setiap butir-butir kriteria pada angket, mendapat skor respon yang tinggi sehingga memenuhi tingkat kepraktisan yang tinggi. Ketika data tersebut diolah menggunakan rumus $P_{a}=\frac{\sum_{i=1}^{n} V_{i}}{n}$, menunjukkan bahwa hasil $\boldsymbol{P}_{\boldsymbol{a}}$ (rerata skor kepraktisan untuk semua butir) respon guru adalah 4 . Oleh karena itu, dapat disimpulkan LKS bersifat praktis.

Adapun hasil tes siswa dalam uji coba kelompok kecil dan uji coba kelompok besar adalah sebagai berikut.

Tabel 6 Hasil Skor Tes Uji Coba Kelompok Kecil

\begin{tabular}{llll}
\hline No & Subjek & Skor Tes & Keterangan \\
\hline 1 & AP & 89 & Lolos KKM \\
\hline 2 & DF & 77 & Lolos KKM \\
\hline 3 & LTF & 94 & Lolos KKM \\
\hline 4 & RW & 75 & Lolos KKM \\
\hline
\end{tabular}

Paparan data pada Tabel 6 menunjukkan bahwa subjek lolos KKM sehingga diperolah presentase $100 \%$ subjek lolos KKM. Oleh karena itu, dapat disimpulkan LKS bersifat efektif.

Tabel 7 Hasil Skor Tes Uji Coba Kelompok Besar

\begin{tabular}{l|l|l|l}
\hline No & Subjek & Skor Tes & Keterangan \\
\hline 1 & AG & 66 & Tidak Lolos KKM \\
\hline 2 & DA & 65 & Tidak Lolos KKM \\
\hline 3 & HS & 84 & Lolos KKM \\
\hline 4 & NK & 88 & Lolos KKM \\
\hline 5 & ASP & 89 & Lolos KKM \\
\hline 6 & DDP & 85 & Lolos KKM \\
\hline 7 & HR & 90 & Lolos KKM \\
\hline 8 & NA & 77 & Lolos KKM \\
\hline 9 & DM & 80 & Lolos KKM \\
\hline 10 & IK & 86 & Lolos KKM \\
\hline 11 & MRA & 87 & Lolos KKM \\
\hline 12 & RA & 77 & Lolos KKM \\
\hline 13 & IM & 82 & Lolos KKM \\
\hline 14 & NYJ & 72 & Lolos KKM \\
\hline
\end{tabular}




\begin{tabular}{l|l|l|l}
\hline 15 & RER & 76 & Lolos KKM \\
\hline 16 & S & 100 & Lolos KKM \\
\hline 17 & AYS & 75 & Lolos KKM \\
\hline 18 & JPS & 96 & Lolos KKM \\
\hline 19 & STW & 96 & Lolos KKM \\
\hline 20 & YDO & 81 & Lolos KKM \\
\hline 21 & AS & 81 & Lolos KKM \\
\hline 22 & DRP & 88 & Lolos KKM \\
\hline 23 & FW & 81 & Lolos KKM \\
\hline
\end{tabular}

Paparan data pada Tabel 7 menunjukkan bahwa 21 dari 23 subjek lolos KKM sehingga diperolah presentase $91 \%$ subjek lolos KKM. Oleh karena itu, dapat disimpulkan LKS bersifat efektif.

\section{Simpulan}

Berdasarkan hasil uji kevalidan LKS yang telah dipaparkan, diperolah bahwa LKS yang dikembangkan memenuhi kriteria valid. Berdasarkan uji kelompok kecil dan uji kelompok besar dinyatakan bahwa LKS mendapat respon yang baik ditunjukkan oleh angket respon guru dan siswa, sehingga LKS memenuhi kriteria praktis. Sedangkan berdasarkan hasil tes siswa baik uji kelompok besar maupun kecil diperoleh bahwa siswa memenuhi kriteria efektif.

Meskipun demikian LKS yang dikembangkan tentu memiliki kelebihan dan kekurangan. Terdapat beberapa kelebihan LKS yang dikembangkan diantaranya adalah manfaat lapisan penugasan berdasarkan Pirie Kieren yang mampu menggiring siswa memahami materi dengan baik. Misalnya lapisan penugasan primitive knowing membantu siswa mengingat kembali materi prasyarat, lapisan penugasan image making membantu siswa membangun pengetahuan baru melalui pengetahuan lampau yang dimiliki, dan lain sebagainya. LKS yang dikembangkan juga membantu peserta didik memahami fungsi linier dengan baik terbukti dari hasil skor siswa yang 91\% lolos KKM. Selain itu, LKS yang dikembangkan membantu siswa membangun pemahaman matematis secara mandiri, sehingga guru hanya sebagai fasilitator.

Beberapa kekurangam LKS yang dikembangkan diantaranya, LKS yang dikembangkan hanya terbatas pada materi fungsi linier kelas X SMA/MA. LKS disesuaikan dengan karakteristik siswa kelas X SMA Nasional Malang sehinga untuk karakteristik peserta didik yang berbeda membutuhkan uji coba lebih lanjut. Selain itu, siswa belum berani mengutarakan pertanyaan kritis pada bagian inventising.

Lembar kegiatan siswa hasil pengembangan ini diharapkan dapat menjadi contoh untuk dikembangkannya LKS Pirie Kieren dengan materi dan jenjang kelas lain. LKS ini hendaknya juga dapat dijadikan sebagai alternatif bahan ajar untuk melaksanakan pembelajaran fungsi linier. Selain itu besar harapan penulis akan ada penelitian lebih lanjut untuk mengembangkan LKS Pirie Kieren yang bertujuan untuk mengasah kemampuan matematis yang lain. Misalnya kemampuan koneksi, representasi, bahkan komunikasi matematis. 


\section{Daftar Rujukan}

Cahyati, A. M. D., \& Kriswandani, K. (2017). Lapisan pemahaman konsep matematika dalam menyelesaikan soal timss bagi siswa SMP kelas VIII. Inspiramatika, 3(2), 83-97.

Depdiknas. (2008). Panduan pengembangan bahan ajar. Direktorat Jenderal Manajemen Pendidikan Dasar dan Menengah Direktorat Pembinaan Sekolah Menengah Atas. Tidak diterbitkan.

Hobri, H. (2010). Metodologi penelitian pengembangan (aplikasi pada penelitian pendidikan matematika). Jember: Pena Salsabila.

Peraturan Menteri Pendidikan dan Kebudayaan Republik Indonesia Nomor 58 Tahun 2014 Tentang Kurikulum 2013 SMP/MTs.

Kementerian Pendidikan dan Kebudayaan. Nomor 58. tahun 2014 tentang Kurikulum 2013 Sekolah menengah Pertama. Madrasah Tsanawiyah.

Pirie, S., \& Kieren, T. (1994). Growth in mathematical understanding: How can we characterise it and how can we represent it?. In Learning Mathematics (pp. 61-86). Springer, Dordrecht.

Plomp, T. (2013). Educational design research: An introduction. Educational design research, 11-50.

Schwartz, R. S., Gfeller, M. K., \& Lederman, N. G. (2001). Integrating Science and Mathematics: A natural connection or strange bedfellows. In annual conference of Association for the Education of Teachers in Science, Costa Mesa, CA.

Sutisna, A. P., Maulana, M., \& Subarjah, H. (2016). Meningkatkan pemahaman matematis melalui pendekatan tematik dengan RME. Jurnal Pena Ilmiah, 1(1), 31-40. 